\title{
Datarapportage Marktbemonstering schubvis IJsselmeergebied 2019
}

Auteur(s): $\quad$ Karen Kwakman-Schilder \& Joey Volwater

Dit onderzoek is uitgevoerd door Wageningen Marine Research in opdracht van en gefinancierd door het Ministerie van Landbouw, Natuur en Voedselkwaliteit, in het kader van het Beleidsondersteunend onderzoekthema 'Zoet' (projectnummer BO-43-023.02002). 
Opdrachtgever: Ministerie van Landbouw, Natuur en Voedselkwaliteit

T.a.v.: de heer Vincent van der Meij

Bezuidenhoutseweg 73

2594 AC Den Haag

Bas code: BO-43-023.02-002

Project nummer: 4318100284

Dit rapport is gratis te downloaden van https://doi.org/10.18174/527692

Wageningen Marine Research verstrekt geen gedrukte exemplaren van rapporten.

Wageningen Marine Research is ISO 9001:2015 gecertificeerd.

\section{(C) Wageningen Marine Research}

Wageningen Marine Research, instituut binnen de rechtspersoon Stichting

Wageningen Research, hierbij vertegenwoordigd door Dr. M.C.Th. Scholten, Algemeen directeur

KvK nr. 09098104,

WMR BTW nr. NL 8113.83.696.B16.

Code BIC/SWIFT address: RABONL2U

IBAN code: NL 73 RABO 0373599285
Wageningen Marine Research aanvaardt geen aansprakelijkheid voor gevolgschade, noch voor schade welke voortvloeit uit toepassingen van de resultaten van werkzaamheden of andere gegevens verkregen van Wageningen Marine Research. Opdrachtgever vrijwaart Wageningen Marine Research van aanspraken van derden in verband met deze toepassing.

Alle rechten voorbehouden. Niets uit deze uitgave mag weergegeven en/of gepubliceerd worden, gefotokopieerd of op enige andere manier gebruikt worden zonder schriftelijke toestemming van de uitgever of auteur. 


\section{Inhoud}

$\begin{array}{lr}\text { Samenvatting } & 4\end{array}$

$\begin{array}{llr}1 & \text { Inleiding } & 5\end{array}$

2 Methoden $\quad 6$

2.1 Doelsoorten en metingen 6

$\begin{array}{ll}2.2 & \text { Planning veldbezoeken }\end{array}$

$\begin{array}{ll}2.3 \text { Uitvoering } & 7\end{array}$

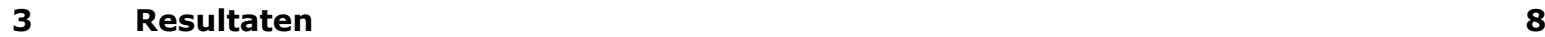

3.1 Algemene gegevens $\quad 8$

$\begin{array}{ll}3.2 \text { Vangstgegevens } & 10\end{array}$

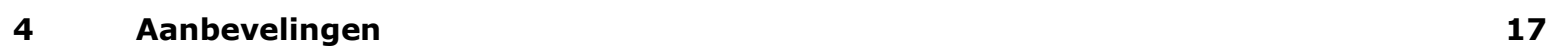

$\begin{array}{llr}5 & \text { Kwaliteitsborging } & 18\end{array}$

$\begin{array}{lr}\text { Verantwoording } & 19\end{array}$

$\begin{array}{llr}\text { Bijlage } 1 \quad \text { Lengte-frequentie gegevens overige vangsten } & 20\end{array}$ 


\section{Samenvatting}

Het ministerie van Landbouw, Natuur en Voedselkwaliteit (LNV) is in het kader van de Visserijwet verantwoordelijk voor een duurzame visserij op snoekbaars, baars, blankvoorn en brasem op het IJsselmeer en Markermeer. Het ministerie heeft hierbij het uitgangspunt het beheer te baseren op wetenschappelijk onderbouwde vangst- en inspanningsadviezen. Een belangrijke informatiebron voor nauwkeurige visserijadviezen is informatie over de vangstopbouw van de visserij; wat is de lengte- en leeftijdsopbouw van de vangst? Deze informatie wordt voor deze vier bestanden sinds 2016 in een marktbemonstering aan boord van de schepen verzameld. Om informatie over de vier bestanden te krijgen worden tijdens het eerste, derde en vierde kwartaal de twee grootste visserijen in het IJsselmeer en Markermeer bemonsterd, namelijk de staandwantvisserij (waarbij voornamelijk met $101 \mathrm{~mm}$ maaswijdte en soms met grotere mazen wordt gevist) en de zegenvisserij.

In totaal zijn in 201937 visreizen uitgevoerd, waarbij 32 bij de staandwantvisserij en 5 bij de zegenvisserij. Bij zegenvisserij zijn in totaal 9 trekken uitgevoerd. Daarbij zijn verdeeld over de visserijen 17424 vissen gevangen. Van de doelsoorten waren dit 1421 baarzen, 4343 blankvoorns, 4521 brasems en 6549 snoekbaarzen. In totaal zijn 16 vissoorten gevangen, daarnaast is ook wolhandkrab en rivierkreeft gevangen.

De gemiddelde lengte van doelsoorten gevangen in het $101 \mathrm{~mm}$-staandwantnet varieerde over de meren en kwartalen voor baars tussen $26.1-35.5 \mathrm{~cm}$, voor blankvoorn tussen $29.2-30.9 \mathrm{~cm}$, voor brasem tussen $33.3-38.1 \mathrm{~cm}$ en voor snoekbaars tussen $43.4-50.5 \mathrm{~cm}$.

Het percentage van de vangst dat ondermaats was varieerde over de meren en kwartalen voor baars tussen $0.2-23 \%$ en voor snoekbaars tussen $0.4-11.8 \%$. Voor blankvoorn en brasem is geen minimummaat voor aanlanding.

In totaal zijn in 2019467 vissen verzameld voor biologische gegevens, waarvan 122 baarzen, 110 blankvoorns, 132 brasems en 103 snoekbaarzen.

Voor alle soorten zijn vanaf het derde kwartaal per veldbezoek schattingen van de discards gemaakt. De doelsoort die het meest teruggezet werd is brasem, daarnaast werd voor alle soorten meer overboord gezet in het derde dan in het vierde kwartaal.

Het bezoeken van de zegenvisserij blijkt een probleem te zijn. In het eerste kwartaal is het 5 van de 6 geplande keren gelukt aan boord te komen. Voor het vierde kwartaal was gepland om 12 veldbezoeken bij de zegenvisserij uit te voeren. Het is echter geen enkele keer gelukt om aan boord te komen. Wij bevelen aan om in nader overleg tussen het Ministerie van LNV, de visserijsector en Wageningen Marine Research te bepalen hoe we dit kunnen oplossen. 


\section{$1 \quad$ Inleiding}

Het ministerie van Landbouw, Natuur en Voedselkwaliteit (LNV) is in het kader van de Visserijwet verantwoordelijk voor een duurzame visserij op snoekbaars, baars, blankvoorn en brasem op het IJsselmeer en Markermeer. Het ministerie heeft hierbij het uitgangspunt het beheer te baseren op wetenschappelijk onderbouwde vangst- en inspanningsadviezen. Een belangrijk informatiebron voor nauwkeurige visserijmodellen is informatie over de vangstopbouw van de visserij; wat is de lengte- en leeftijdsopbouw van de vangst? Deze informatie wordt voor deze vier bestanden sinds 2016 in een marktbemonstering aan boord van de schepen verzameld. Om informatie over de vier bestanden te krijgen worden de twee grootste visserijen in het IJsselmeer en Markermeer bemonsterd, namelijk de staandwantvisserij (waarbij voornamelijk met $101 \mathrm{~mm}$ maaswijdte en soms met grotere mazen wordt gevist) en de zegenvisserij. Deze rapportage geeft een overzicht van de verzamelde gegevens tijdens de marktbemonstering in 2019.

\section{Achtergrond marktbemonstering}

Voor visserijadviezen is informatie over de opbouw van de commerciële vangsten gewenst; wat is de lengteen leeftijdsopbouw van de vangsten? Samen met de logboeken van beroepsvissers geeft dit een beeld van de jaarlijkse vangsten per leeftijd, wat een essentieel onderdeel is van de visserijmodellen. Verder is voor visserijadviezen informatie benodigd over de biologie van een bestand (groei, voortplanting etc.). Deze informatie ontbreekt deels voor met name de grotere schubvissen, omdat deze in de wetenschappelijke surveys in lagere aantallen worden aangetroffen. De marktbemonstering voor schubvis is opgezet om gegevens te verzamelen over de samenstelling van de vangst (lengte, leeftijd, gewicht) en het vaststellen van biologische parameters (groei, voortplanting).

In 2016 en 2017 zijn eerste pilot studies uitgevoerd. Hierbij zijn beroepsvissers vissend op schubvis (met name baars, brasem, blankvoorn en snoekbaars) bezocht aan boord ten tijde van visserijactiviteiten, welke voornamelijk staandwantvisserij, maar ook zegenvisserij betrof. Op basis van de resultaten uit de pilotstudies is besloten om de marktbemonstering voort te zetten. Deze rapportage geeft een overzicht van de gegevens die verzameld zijn in 2019.

\section{Doelstelling}

Het doel van dit onderzoek is:

1. Het bemonsteren van de lengtesamenstelling van de schubvisvangsten uit het IJsselmeer en Markermeer van 2019 gedurende veldbezoeken aan boord van vissersschepen.

2. Het analyseren van vismonsters (leeftijd, gewicht, geslacht, rijpheid) in het lab. 


\section{Methoden}

De marktbemonstering schubvis van 2019 was in grote lijnen opgedeeld in vier stappen:

1. Telefonisch benaderen van beroepsvissers voor het maken van een afspraak voor een veldbezoek

2. Veldbezoeken, waarbij de lengtesamenstelling werd doorgemeten

3. Het analyseren van biologische gegevens op basis van opgekochte vis

4. Verwerken van de verzamelde gegevens

\subsection{Doelsoorten en metingen}

De doelsoorten van de marktbemonstering schubvis zijn: snoekbaars, baars, brasem en blankvoorn. Tijdens veldbezoeken werd alle vis inclusief de bijvangst opgemeten. Sinds het derde kwartaal van 2019 wordt ook per trip bijgehouden welke vis overboord gezet werd. De lengte van de vis werd naar de centimeter beneden gemeten waarbij de staartvin samengeknepen werd. Dit houdt bijvoorbeeld in dat $39.9 \mathrm{~cm}$ wordt afgerond naar $39 \mathrm{~cm}$.

Daarnaast is in het eerste en vierde kwartaal snijvis verzameld voor biologische metingen. Omdat in het verleden vaak gebleken is dat bij de marktbemonstering alleen niet genoeg snijvis verzameld kon worden is besloten om in het vierde kwartaal ook snijvis uit de staandwantsurvey te verzamelen. De staandwantsurvey wordt door WMR in samenwerking met de beroepsvisserij uitgevoerd in het vierde kwartaal. Deze survey gebruikt staandwantnetten bestaande uit panelen met verschillende maaswijdtes. Gedurende deze survey is gebleken dat relatief eenvoudig meerdere lengteklassen kunnen worden verzameld voor biologische gegevens. Tevens kan bij de staandwantsurvey meer ondermaatse vis worden verzameld dan bij de marktbemonstering.

Het streven hierbij was om voor baars en blankvoorn 10 vissen per $2 \mathrm{~cm}$ lengteklasse te verzamelen en van snoekbaars en brasem 10 vissen van elke $3 \mathrm{~cm}$ klasse. Van de verzamelde vissen is de leeftijd, geslacht, rijpheid en gewicht bepaald. De leeftijden zijn bepaald op basis van schubben, daarbij zijn voor baars ook de vinstralen gebruikt.

\subsection{Planning veldbezoeken}

De veldbezoeken werden verdeeld per kwartaal: kwartaal een (januari-maart), kwartaal drie (juliseptember) en kwartaal vier (oktober-december). Voor de marktbemonstering is ervoor gekozen om aan boord te stappen van de vissers. Dit heeft de voorkeur boven het meten of opkopen aan de wal. Door aan boord te stappen wordt een relatie opgebouwd met de beroepsvisserij en wordt een goed inzicht in de type visserijen verkregen. Daarnaast wordt bij het aan boord stappen informatie over de gehele vangst verzameld terwijl het opkopen aan de wal alleen informatie over de aanlandingen geeft.

Voor de marktbemonstering 2019 was het de bedoeling dat in kwartaal een, drie en vier in totaal twaalf veldbezoeken per kwartaal uitgevoerd zouden worden bij $101 \mathrm{~mm}$-staandwantvissers en zegenvissers gedurende hun werkzaamheden. Omdat de marktbemonstering opgezet is om een representatief beeld te krijgen van de totale vangstsamenstelling van de staandwant- en zegenvisserij op snoekbaars, baars, blankvoorn en brasem, wordt de verdeling waarin vistuigen bemonsterd worden jaarlijks gebaseerd op een analyse van logboekgegevens van IJsselmeer- en Markermeervissers. Op deze manier wordt de bemonsteringsinzet zo verdeeld over de twee visserijen dat een zo representatief mogelijk beeld ontstaat door de tijd en ruimte heen. 
Voor het eerste kwartaal was de planning om zes veldbezoeken bij de zegenvisserij en zes veldbezoeken bij de staandwantvisserij uit te voeren. Daarnaast was het zowel bij de zegen- als de staandwantvisserij de bedoeling om zo'n vier à vijf van de zes bezoeken in het Markermeer te doen.

In het derde en vierde kwartaal was de planning om in totaal minimaal twaalf veldbezoeken bij de staandwantvisserij met een $101 \mathrm{~mm}$ maaswijdte net uit te voeren, en daarbij de helft op het IJsselmeer en de helft op het Markermeer. Daarnaast was het plan om gedurende het derde en vierde kwartaal de overige twaalf veldbezoeken zoveel mogelijk bij de zegenvisserij uit te voeren. Als het niet zou lukken om de overige 12 bezoeken bij de zegenvisserij uit te voeren, zouden bij voorkeur nog enkele trips bij de staandwantvisserij die een grotere maaswijdte hanteren plaats kunnen vinden. Voor deze laatste twaalf veldbezoeken voor de zegenvisserij was het de bedoeling dat 75\% op het Markermeer uitgevoerd zou worden.

\section{$2.3 \quad$ Uitvoering}

In 2019 werden de veldwerkzaamheden van de marktbemonstering uitgevoerd door FishNED Consultancy. FishNED was verantwoordelijk voor het telefonisch benaderen van beroepsvissers, het uitvoeren van de veldbezoeken, het documenteren van de vangsten tijdens de veldbezoeken en het opkopen van snijvis in het vierde kwartaal.

Binnen WMR werden de biologische gegevens van de snijvis verzameld, de data verwerkt en geanalyseerd. 


\section{Resultaten}

\subsection{Algemene gegevens}

\section{Overzicht veldbezoeken 2019}

In totaal zijn in 201937 visreizen uitgevoerd bij de staandwant- en zegenvisserij, waarbij 32 bij de staandwantvisserij en 5 bij de zegenvisserij. Bij zegenvisserij zijn in totaal 9 trekken uitgevoerd. De visserij op het Markermeer is 22 keer bezocht en de visserij op het IJsselmeer 15 keer (tabel 1, figuur 1).

Het geplande aantal trips verdeeld over de visserijen is daarbij voor de zegenvisserij niet gehaald. In plaats daarvan zijn extra visreizen bij de staandwantvisserij uitgevoerd (tabel 2).

Tabel 1. Overzicht van het aantal vaartrips per maand per vistuig en een overzicht van het aantal vaartrips per maand per meer (IJssel- of Markermeer). Voor de vistuigen $101-130 \mathrm{~mm}$ en $101-140 \mathrm{~mm}$ zijn 8 netten met maaswijdte $101 \mathrm{~mm}$ en 8 netten met een grote maaswijdte gebruikt.

\begin{tabular}{|c|c|c|c|c|c|c|c|c|c|c|c|c|c|}
\hline & jan & feb & maa & apr & mei & jun & jul & aug & sep & okt & nov & dec & Totaal \\
\hline Zegen $(80 \mathrm{~mm})$ & $\begin{array}{r}3(6 \\
\text { trekken) }\end{array}$ & & $\begin{array}{r}2(3 \\
\text { trekken) }\end{array}$ & & & & & & & & & & 5 \\
\hline $101 \mathrm{~mm}$ & 1 & 2 & 3 & & & & 4 & 4 & 3 & 3 & 3 & 5 & 28 \\
\hline $130 \mathrm{~mm}$ & & & & & & & 1 & & & & & & 1 \\
\hline $140 \mathrm{~mm}$ & & & & & & & & & & & & 1 & 1 \\
\hline $101-130 \mathrm{~mm}$ & & 1 & & & & & & & & & & & 1 \\
\hline $101-140 \mathrm{~mm}$ & & 1 & & & & & & & & & & & 1 \\
\hline IJsselmeer & & 2 & & & & & 4 & & 2 & 3 & 3 & 1 & 15 \\
\hline Markermeer & 4 & 2 & 5 & & & & 1 & 4 & 1 & & & 5 & 22 \\
\hline Totaal & 4 & 4 & 5 & & & & 5 & 4 & 3 & 3 & 3 & 6 & 37 \\
\hline
\end{tabular}

Tabel 2. Geplande en gerealiseerde visreizen

\begin{tabular}{|l|l|r|r|r|r|}
\hline & & \multicolumn{2}{|c|}{ Eerste kwartaal } & \multicolumn{2}{c|}{ derde en vierde kwartaal } \\
\hline & & Gepland & Gerealiseerd & Gepland & Gerealiseerd \\
\hline Staandwantvisserij & Markermeer & $4-5$ & 6 & 6 & 11 \\
\hline & IJsselmeer & $1-2$ & 2 & 6 & 13 \\
\hline Zegenvisserij & Markermeer & $4-5$ & 5 & 9 & 0 \\
\hline & IJsselmeer & $1-2$ & 0 & 3 & 0 \\
\hline
\end{tabular}




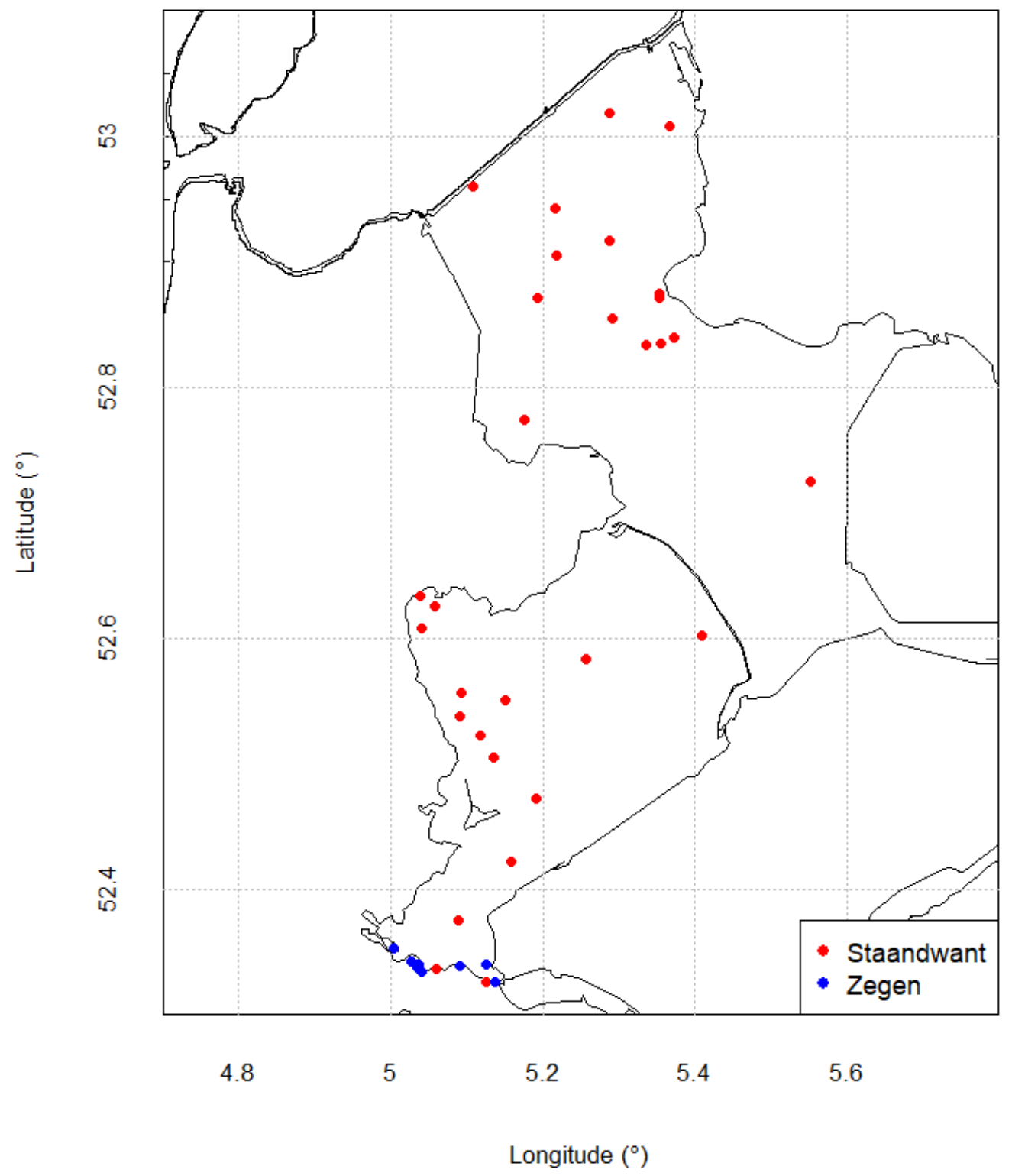

Figuur 1. Ruimtelijke verdeling van de vaartrips en trekken. In rood zijn de uitgevoerde vaartrips met het staandwantnet en in blauw zijn uitgevoerde trekken met een zegen. 


\subsection{Vangstgegevens}

\section{Soorten en aantallen vis}

In totaal zijn 17424 vissen gevangen en doorgemeten tijdens de veldbezoeken in 2019 (Tabel 3 en 4). Van de doelsoorten waren dit 1421 baars, 4343 blankvoorn, 4521 brasem en 6549 snoekbaars. Daarnaast zijn twaalf andere vissoorten gevangen, waarvan 590 exemplaren gemeten zijn. Het grootste gedeelte hiervan was bot, waarvan 300 exemplaren gemeten zijn. Daarnaast zijn ook 107 Chinese wolhandkrabben en twintig gevlekte Amerikaanse rivierkreeften gevangen.

Tabel 3. Overzicht van de totale vangstgegevens per meer per kwartaal van alle vistuigen gesommeerd.

\begin{tabular}{|c|c|c|c|c|c|c|c|}
\hline Meer & IJM & MM & IJM & MM & IJM & MM & Totaal \\
\hline Kwartaal & 1 & 1 & 3 & 3 & 4 & 4 & \\
\hline Aantal vaartrips & 2 & 11 & 6 & 6 & 7 & 5 & 37 \\
\hline Atlantische forel & & & 2 & & & & 2 \\
\hline Baars & 32 & 483 & 257 & 332 & 178 & 139 & 1421 \\
\hline Blankvoorn & 95 & 846 & 768 & 655 & 188 & 1791 & 4343 \\
\hline Bot & 8 & 69 & 187 & 4 & 31 & 1 & 300 \\
\hline Brasem & 70 & 1797 & 722 & 1266 & 273 & 393 & 4521 \\
\hline Europese meerval & & 1 & & & & & 1 \\
\hline Karper & & 1 & & & & & 1 \\
\hline Kolblei & & & 78 & 1 & & & 79 \\
\hline Kroeskarper & & 12 & & & 1 & & 13 \\
\hline Noordzeehouting & 19 & 8 & 1 & 1 & 38 & & 67 \\
\hline Pos & & & 2 & & & & 2 \\
\hline Roofblei & 3 & 9 & 1 & 2 & & & 15 \\
\hline Snoek & & 43 & 2 & 1 & 3 & 4 & 53 \\
\hline Snoekbaars & 85 & 746 & 626 & 3194 & 236 & 1662 & 6549 \\
\hline Spiering & & & & & 7 & & 7 \\
\hline Winde & 2 & 37 & 10 & 1 & & & 50 \\
\hline Chinese wolhandkrab & 26 & 65 & 5 & & & 11 & 107 \\
\hline Gevlekte Amerikaanse rivierkreeft & & 20 & & & & & 20 \\
\hline Totaal & 340 & 4137 & 2661 & 5457 & 955 & 4001 & 17551 \\
\hline
\end{tabular}


Tabel 4. Overzicht van de vangstgegevens gevangen met het staandwantnet of met de zegen per meer.

\begin{tabular}{|c|c|c|c|c|c|}
\hline Meer & IJM & IJM & MM & MM & \\
\hline Tuig & Staandwant & Zegen & Staandwant & Zegen & Totaal \\
\hline Vaartrips & 15 & 0 & 17 & 5 & 37 \\
\hline Atlantische forel & 2 & & & & 2 \\
\hline Baars & 467 & & 937 & 17 & 1421 \\
\hline Blankvoorn & 1051 & & 3230 & 62 & 4343 \\
\hline Bot & 226 & & 71 & 3 & 300 \\
\hline Brasem & 1065 & & 3021 & 435 & 4521 \\
\hline Europese meerval & & & & 1 & 1 \\
\hline Karper & & & 1 & & 1 \\
\hline Kolblei & 78 & & 1 & & 79 \\
\hline Kroeskarper & 1 & & 12 & & 13 \\
\hline Noordzeehouting & 58 & & 6 & 3 & 67 \\
\hline Pos & 2 & & & & 2 \\
\hline Roofblei & 4 & & 11 & & 15 \\
\hline Snoek & 5 & & 21 & 27 & 53 \\
\hline Snoekbaars & 947 & & 5594 & 8 & 6549 \\
\hline Spiering & 7 & & & & 7 \\
\hline Winde & 12 & & 35 & 3 & 50 \\
\hline Totaal & 3925 & 0 & 12940 & 559 & 17424 \\
\hline
\end{tabular}

\section{Lengte-frequentie doelsoorten staandwantvisserij}

Baars

De gemiddelde lengte van de baars gevangen in de $101 \mathrm{~mm}$-staandwantvisserij in het IJsselmeer was in kwartaal drie en vier respectievelijk 32.4 en $26.1 \mathrm{~cm}$ (Tabel 6). De gemiddelde lengte van baars gevangen in de staandwantvisserij in het Markermeer was in het eerste, derde en vierde kwartaal achtereenvolgens 32.5, 32.1 en $31.5 \mathrm{~cm}$. Bij de $101 \mathrm{~mm}$-staandwantvisserij was in het IJsselmeer in het derde en vierde kwartaal respectievelijk $6.6 \%$ en $23 \%$ van de vangst aan baars ondermaats (tabel 5 ). In het Markermeer was $0.2 \%$ van de vangst in het eerste kwartaal ondermaats. In het derde en vierde kwartaal is geen ondermaatse baars gevangen in het Markermeer.

De bandbreedte aan lengte van gevangen baars uit de $101 \mathrm{~mm}$-staandwantvisserij van het IJsselmeer en Markermeer samen was in het eerste kwartaal van $20199-46 \mathrm{~cm}$, in het derde kwartaal $9-47 \mathrm{~cm}$ en in het vierde kwartaal $8-43 \mathrm{~cm}$ (figuur 2).

\section{Blankvoorn}

De gemiddelde lengte van de gevangen blankvoorn in de $101 \mathrm{~mm}$-staandwantvisserij in het IJsselmeer was zowel in kwartaal 3 als kwartaal $430.9 \mathrm{~cm}$ (tabel 6). De gemiddelde lengte van blankvoorn gevangen in de staandwantvisserij in het Markermeer was in het eerste, derde en vierde kwartaal achtereenvolgens 29.2, 30.0 en $30.6 \mathrm{~cm}$.

De bandbreedte aan lengte van gevangen blankvoorn uit de $101 \mathrm{~mm}$-staandwantvisserij van het IJsselmeer en Markermeer samen was in het eerste kwartaal van $201919-37 \mathrm{~cm}$, in het derde kwartaal $21-39 \mathrm{~cm}$ en in het vierde kwartaal $17-37 \mathrm{~cm}$ (figuur 2).

\section{Brasem}

De gemiddelde lengte van de gevangen brasem in de $101 \mathrm{~mm}$-staandwantvisserij in het IJsselmeer was in het derde en vierde kwartaal respectievelijk 33.3 en $34.9 \mathrm{~cm}$ (tabel 6). De gemiddelde lengte in het Markermeer in het eerste, derde en vierde kwartaal was achtereenvolgens $38.1,34.2$ en $33.9 \mathrm{~cm}$. De bandbreedte aan lengte van gevangen brasem uit de $101 \mathrm{~mm}$-staandwantvisserij van het IJsselmeer en 
Markermeer samen was in het eerste kwartaal van $201921-70 \mathrm{~cm}$, in het derde kwartaal 21- $64 \mathrm{~cm}$ en in het vierde kwartaal 17 - $54 \mathrm{~cm}$ (figuur 2).

\section{Snoekbaars}

De gemiddelde lengte van gevangen snoekbaars in de $101 \mathrm{~mm}$-staand wantvisserij in het IJsselmeer was in het derde en vierde kwartaal respectievelijk 47 en $43.4 \mathrm{~cm}$ (tabel 4). De gemiddelde lengte in het Markermeer in het eerste, derde en vierde kwartaal was achtereenvolgens $48.5,49.5$ en $50.5 \mathrm{~cm}$. Bij de $101 \mathrm{~mm}$-staandwantvisserij in het IJsselmeer was in het derde en vierde kwartaal respectievelijk $3.4 \%$ en $11.8 \%$ van de snoekbaarsvangst ondermaats (tabel 6 ). In het Markermeer was dit in het eerste, derde en vierde kwartaal achtereenvolgens $7.5 \%, 0.8 \%$ en $0.4 \%$. De bandbreedte aan lengte van gevangen snoekbaars uit de $101 \mathrm{~mm}$-staandwantvisserij van het IJsselmeer en Markermeer samen was in het eerste kwartaal van $201917-71 \mathrm{~cm}$, in het derde kwartaal $10-70 \mathrm{~cm}$ en in het vierde kwartaal $10-77 \mathrm{~cm}$ (figuur 2).

Tabel 6. Overzicht van de gemiddelde lengte van de vier commerciële soorten in de vangsten van het $101 \mathrm{~mm}$-staandwantnet per kwartaal en meer.

\begin{tabular}{|c|c|c|c|c|}
\hline & & Q1 & Q3 & Q4 \\
\hline & Soort & Gem. lengte & Gem. lengte & Gem. lengte \\
\hline IJM & Baars & & 32.4 & 26.1 \\
\hline MM & Baars & 32.5 & 32.1 & 31.5 \\
\hline IJM & Blankvoorn & & 30.9 & 30.9 \\
\hline MM & Blankvoorn & 29.2 & 30.0 & 30.6 \\
\hline IJM & Brasem & & 33.3 & 34.9 \\
\hline $\mathrm{MM}$ & Brasem & 38.1 & 34.2 & 33.9 \\
\hline IJM & Snoekbaars & & 47.0 & 43.4 \\
\hline MM & Snoekbaars & 48.5 & 49.5 & 50.5 \\
\hline
\end{tabular}

Tabel 6. Totaal aantal gevangen baars en snoekbaars per kwartaal per meer $(n)$ en het aandeel van de vangst dat ondermaats is, voor baars kleiner dan $22 \mathrm{~cm}$ en voor snoekbaars kleiner dan $42 \mathrm{~cm}$. Voor deze lengtegegevens is alleen de $101 \mathrm{~mm}$-staandwantbemonstering meegenomen.

\begin{tabular}{|l|l|c|c|c|c|c|c|}
\hline \multicolumn{2}{|l|}{} & \multicolumn{2}{|c|}{ Q1 } & \multicolumn{2}{c|}{ Q3 } & \multicolumn{2}{c|}{ Q4 } \\
\hline & & $\mathbf{n}$ & Ondermaats & $\mathbf{n}$ & Ondermaats & $\mathbf{n}$ & Ondermaats \\
\hline IJM & Baars & & & 257 & $6,6 \%$ & 178 & $23,0 \%$ \\
\hline MM & Baars & 466 & $0,2 \%$ & 332 & & 139 & \\
\hline IJM & Snoekbaars & & & 625 & $3,4 \%$ & 204 & $11,8 \%$ \\
\hline MM & Snoekbaars & 738 & $7,5 \%$ & 3194 & $0,8 \%$ & 1662 & $0,4 \%$ \\
\hline
\end{tabular}



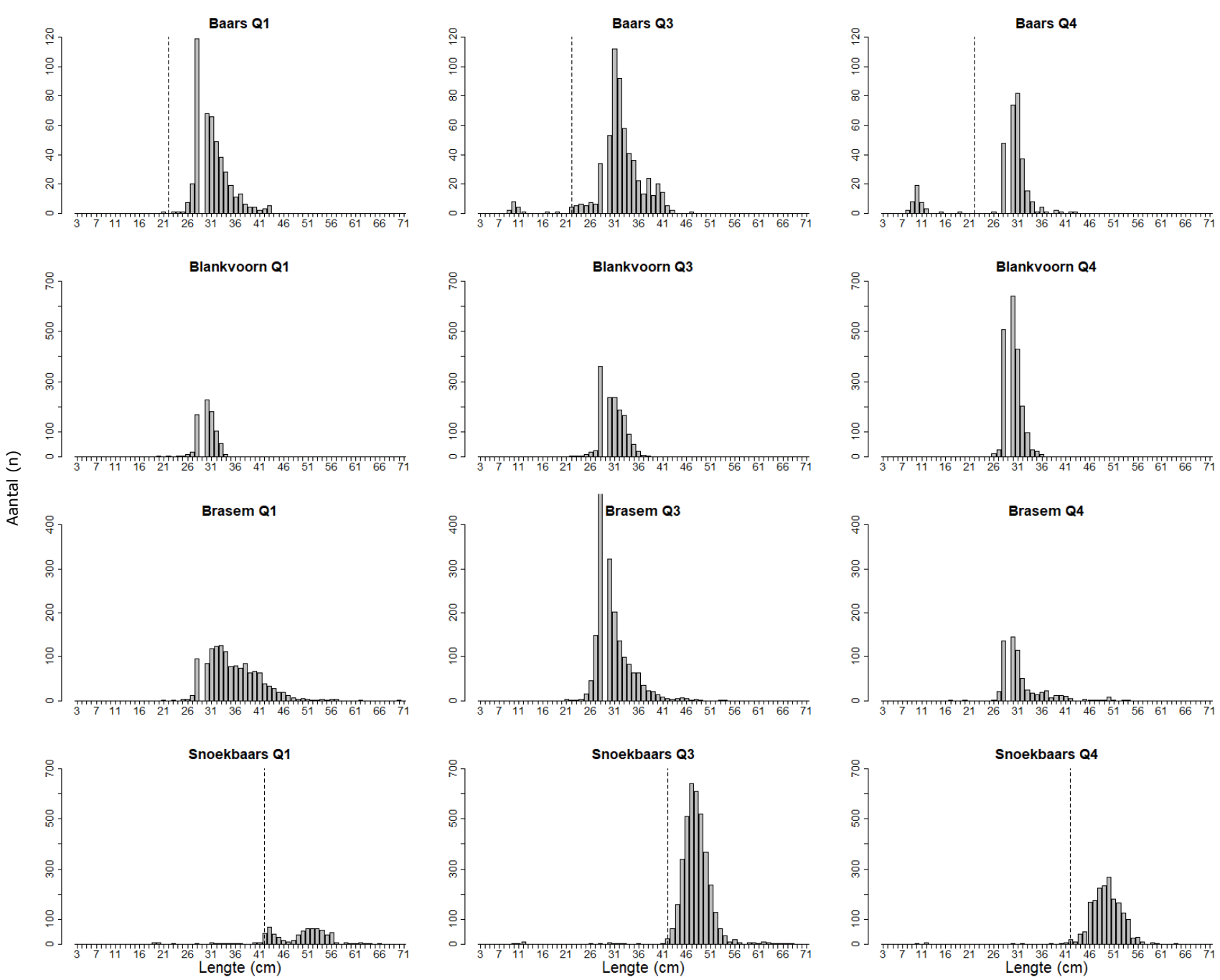

Figuur 2. Lengte frequentie van de vier commerciële soorten per kwartaal. Voor de lengte frequentie zijn alleen de vangsten met het $101 \mathrm{~mm}$ staandwantnet meegenomen en is geen onderscheid gemaakt tussen het IJssel- en Markermeer. De gestreepte verticale lijn bij baars en snoekbaars geeft de minimum aanlandingslengte weer. 


\section{Verzamelde snijvis}

Het streven was om van baars en blankvoorn 10 vissen per $2 \mathrm{~cm}$ lengteklasse te verzamelen en van snoekbaars en brasem 10 vissen van elke $3 \mathrm{~cm}$ klasse. Snoekbaars werd vanaf $15 \mathrm{~cm}$ verzameld en alle andere soorten vanaf $8 \mathrm{~cm}$. Er was van te voren geen maximale lengte voor verzameling vastgesteld. Het is niet gelukt om voor alles soorten het gewenste aantal vissen per klasse te verzamelen omdat deze ook niet gevangen werden (figuur 2). In totaal zijn in 2019467 vissen verzameld voor biologische gegevens, waarvan 122 baarzen, 110 blankvoorns, 132 brasems en 103 snoekbaarzen.

Tabel 5. Aantallen verzamelde snijvis bij de staandwantsurvey en de marktbemonstering per lengteklasse, per soort.

\begin{tabular}{|c|c|c|c|c|c|}
\hline $\begin{array}{c}2 \mathrm{~cm} \\
\text { lengteklasse }\end{array}$ & Baars & Blankvoorn & $\begin{array}{c}3 \mathrm{~cm} \\
\text { lengteklasse }\end{array}$ & Brasem & Snoekbaars \\
\hline $7-8$ & 10 & 0 & $7-9$ & 0 & 0 \\
\hline $9-10$ & 9 & 3 & $10-12$ & 0 & 0 \\
\hline $11-12$ & 11 & 1 & $13-15$ & 1 & 0 \\
\hline $13-14$ & 0 & 5 & $16-18$ & 2 & 10 \\
\hline $15-16$ & 0 & 11 & $19-21$ & 0 & 10 \\
\hline $17-18$ & 3 & 10 & $22-24$ & 2 & 3 \\
\hline $19-20$ & 6 & 9 & $25-27$ & 1 & 0 \\
\hline $21-22$ & 10 & 10 & $28-30$ & 10 & 4 \\
\hline $23-24$ & 6 & 9 & $31-33$ & 8 & 2 \\
\hline $25-26$ & 3 & 11 & $34-36$ & 10 & 10 \\
\hline $27-28$ & 10 & 10 & 37-39 & 10 & 6 \\
\hline $29-30$ & 11 & 9 & $40-42$ & 10 & 10 \\
\hline $31-32$ & 10 & 10 & $43-45$ & 7 & 9 \\
\hline $33-34$ & 10 & 10 & $46-48$ & 16 & 10 \\
\hline $35-36$ & 5 & 1 & $49-51$ & 12 & 11 \\
\hline $37-38$ & 2 & 1 & $52-54$ & 12 & 10 \\
\hline $39-40$ & 4 & 0 & $55-57$ & 11 & 2 \\
\hline $41-42$ & 3 & 0 & $58-60$ & 8 & 1 \\
\hline $43-44$ & 5 & 0 & $61-63$ & 10 & 0 \\
\hline $45-46$ & 2 & 0 & $64-66$ & 2 & 3 \\
\hline $47-48$ & 2 & 0 & $67-69$ & 0 & 1 \\
\hline $49-50$ & 0 & 0 & $70-72$ & 0 & 1 \\
\hline Totaal & 122 & 110 & Totaal & 132 & 103 \\
\hline
\end{tabular}

\section{Discardgegevens doelsoorten}

Het overboord zetten van gevangen vis is afhankelijk van de voorkeur van de visser, de periode en de markt. Qua aantallen is brasem de meest teruggezette vis met een totaal van 1319 vissen in het derde en vierde kwartaal (figuur 3).

Voor de zegen- en staandwantvisserij samen werden voor alle doelsoorten grotere aantallen vis overboord gezet in kwartaal drie dan in kwartaal vier (figuur 4). Dit verschil was het grootst bij brasem, waarvan in het derde kwartaal 1317 vissen teruggezet zijn en in het vierde kwartaal slechts twee.

Voor baars zijn in het derde kwartaal naast ondermaatse individuen ook bovenmaatse baarzen teruggezet. Voor snoekbaars werd alle bovenmaatse vis aangeland, dit is waarschijnlijk te verklaren door de grotere marktwaarde van snoekbaars ten opzichte van baars. 


\section{Discards}

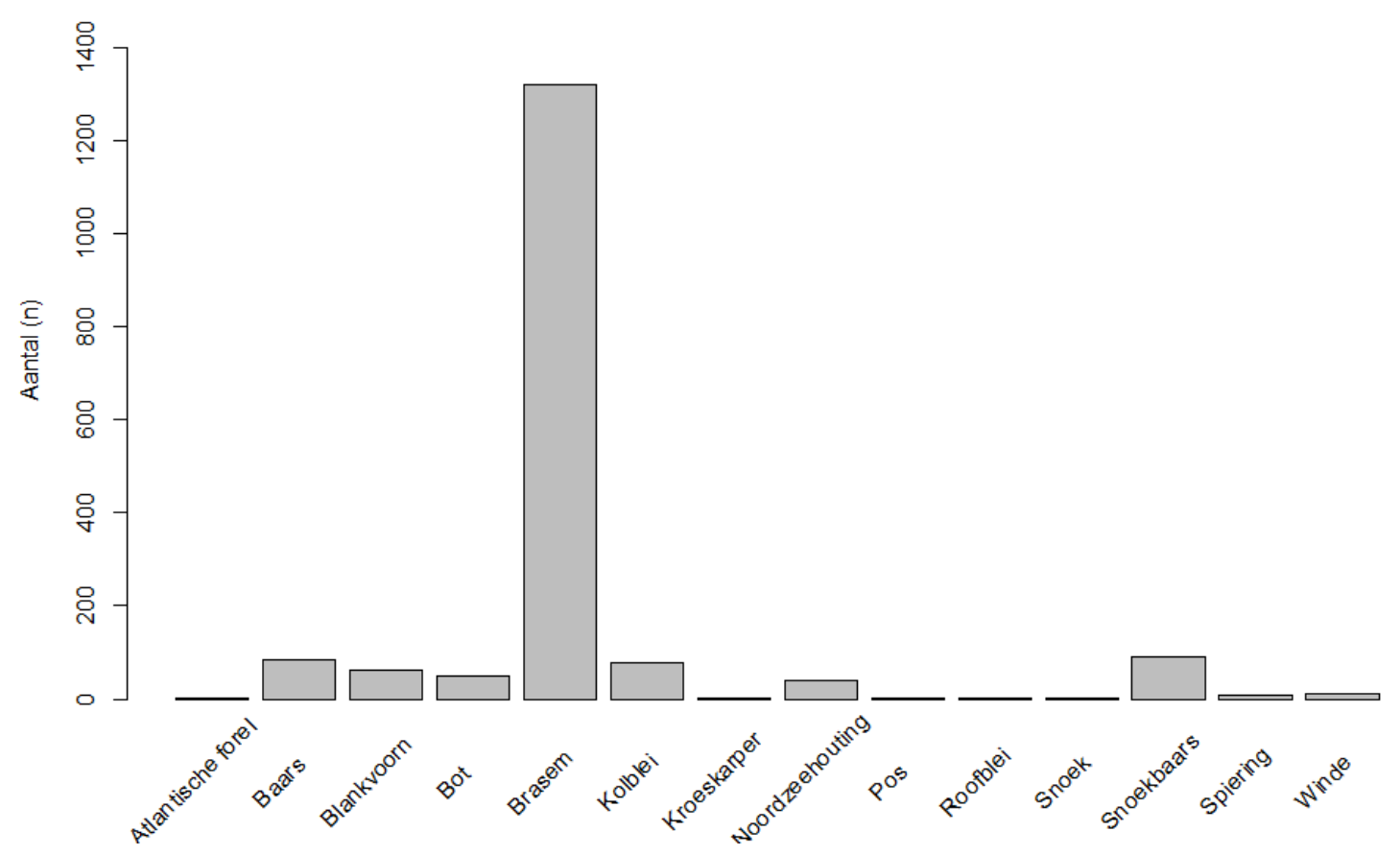

Figuur 3. Aantal vis per soort dat is geregistreerd als discards. Discards zijn alleen geregistreerd in kwartaal drie en vier, dus bovenstaande is een totaal over de twee kwartalen 

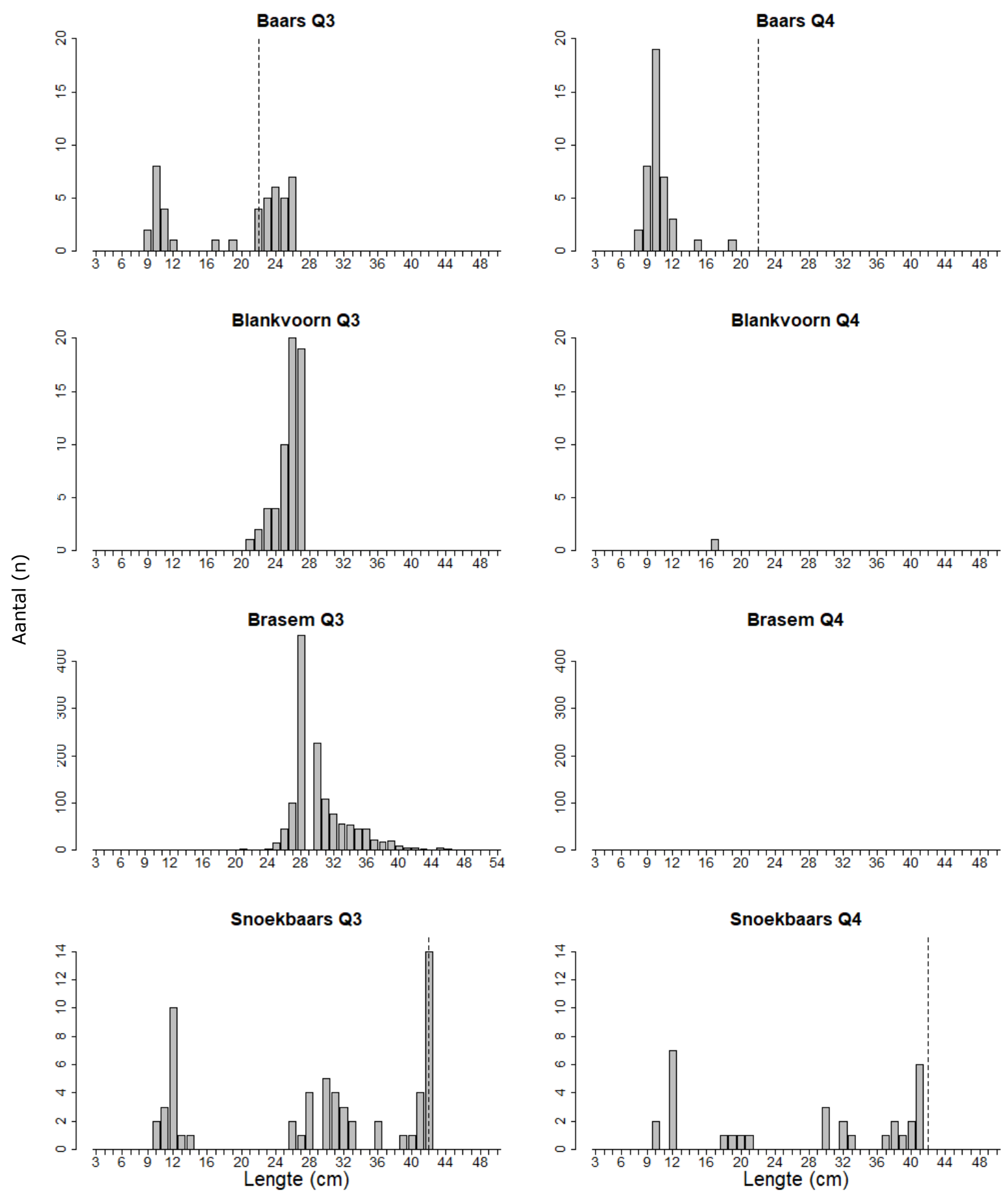

Figuur 4. Lengte frequentie van de vier commerciële soorten per kwartaal geregistreerd als discards. Voor de lengte frequentie zijn alle vangsten meegenomen. De gestreepte verticale lijn bij baars en snoekbaars geeft de minimum aanlandingslengte weer. 


\section{$4 \quad$ Aanbevelingen}

\section{Terugkoppeling samenwerking vissers en aanbevelingen}

Voor de staandwantvisserij zijn in 2019 geen problemen geweest om aan boord van schepen te komen. Alleen het bezoeken van de zegenvisserij blijkt een probleem te zijn. In het eerste kwartaal is het 5 van de 6 geplande keren gelukt aan boord te komen. Voor het vierde kwartaal was gepland om 12 veldbezoeken bij de zegenvisserij uit te voeren. Het is echter geen enkele keer gelukt om aan boord te komen. Wij bevelen aan om in nader overleg tussen het Ministerie van LNV, de visserijsector en Wageningen Marine Research te bepalen hoe we dit kunnen oplossen. 


\section{$5 \quad$ Kwaliteitsborging}

Wageningen Marine Research beschikt over een ISO 9001:2015 gecertificeerd

kwaliteitsmanagementsysteem. Dit certificaat is geldig tot 15 december 2021. De organisatie is gecertificeerd sinds 27 februari 2001. De certificering is uitgevoerd door DNV GL. 


\section{Verantwoording}

Rapport C067/20.

Projectnummer: 4318100284.

Bascode: BO-43-023.02-002.

Dit rapport is met grote zorgvuldigheid tot stand gekomen. De wetenschappelijke kwaliteit is intern getoetst door een collega-onderzoeker en het verantwoordelijk lid van het managementteam van Wageningen Marine Research

Akkoord:

Dr. N.S.H. Tien

Onderzoeker

Handtekening:

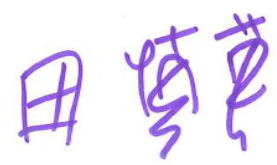

Datum:

22 juli, 2020

Akkoord:

Drs. J. Asjes

Manager Integratie

Handtekening:

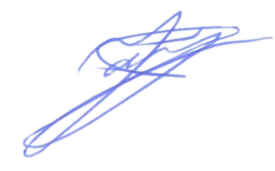

Datum:

22 juli, 2020 


\section{Bijlage 1 Lengte-frequentie gegevens overige vangsten}

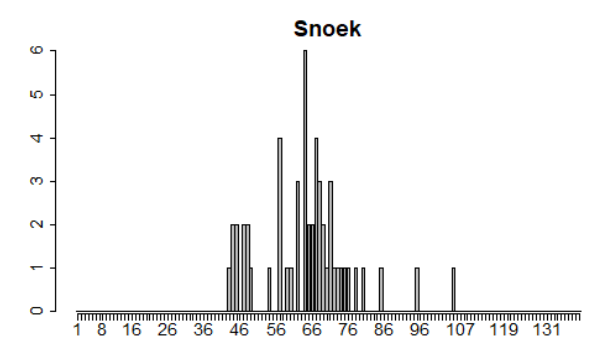

Bot

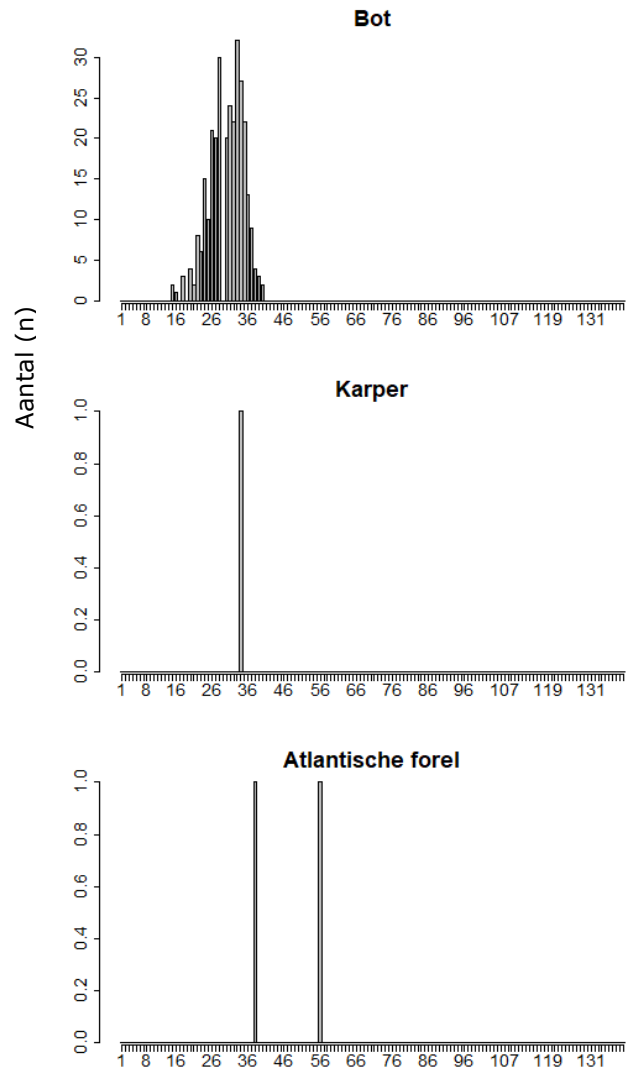

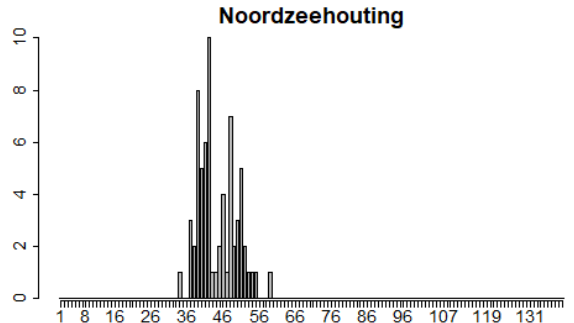
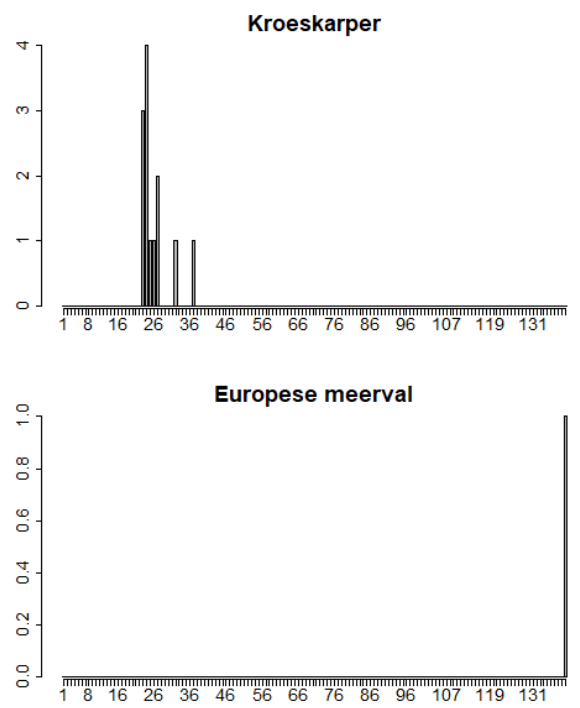

Pos

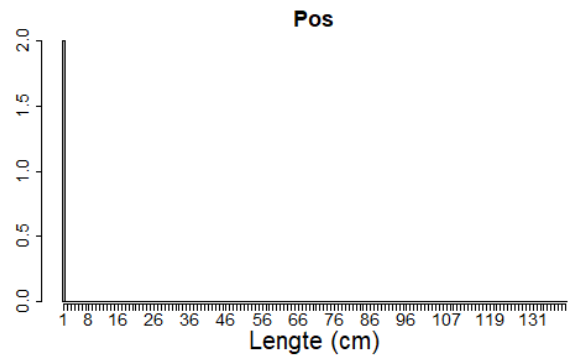

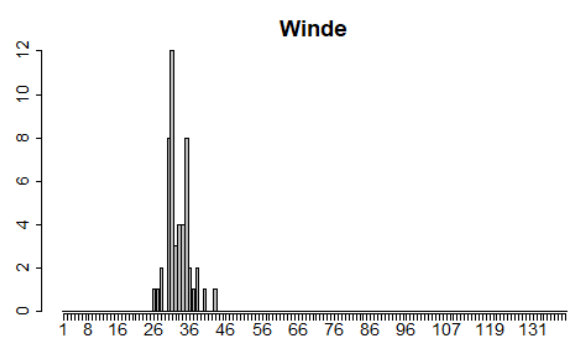

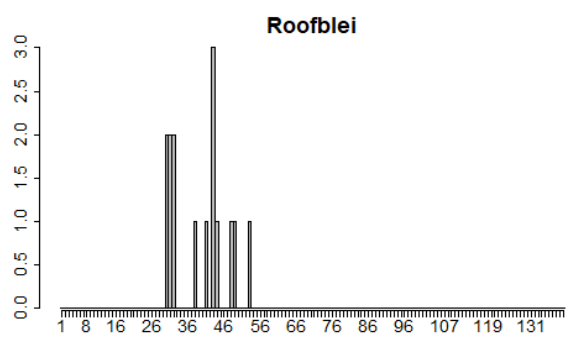

Kolblei

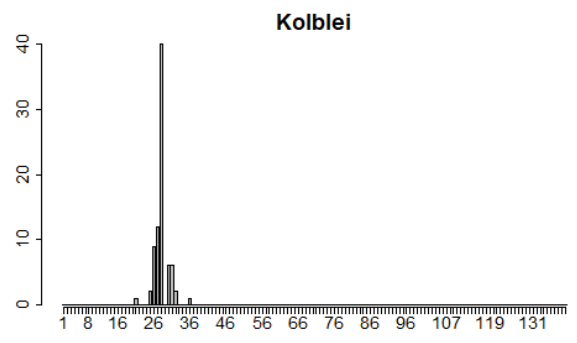

Spiering

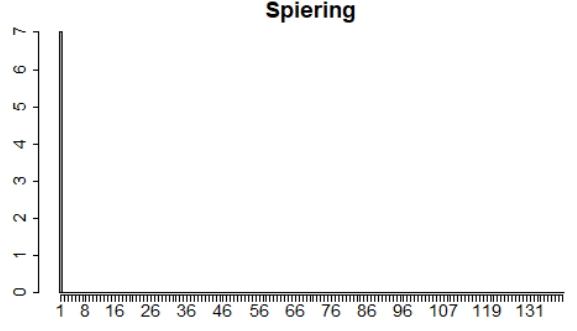

Figuur B1. Overzicht van de lengte-frequentie van de overige soorten (niet commerciële soorten) gevangen tijdens vaartrips in 2019. Zowel de vangsten van de staandwantvisserij als de zegenvisserij zijn meegenomen en geen onderscheid is gemaakt tussen het IJssel- of Markermeer. 
Wageningen Marine Research

$\mathrm{T}:+31(0) 317480900$

E: marine-research@wur.nl

www.wur.nl/marine-research

Bezoekers adres:

- Ankerpark 271781 AG Den Helder

- Korringaweg 7, 4401 NT Yerseke

- Haringkade 1, 1976 CP IJmuiden
Wageningen Marine Research levert met kennis, onafhankelijk wetenschappelijk onderzoek en advies een wezenlijke bijdrage aan een duurzamer, zorgvuldiger beheer, gebruik en bescherming van de natuurlijke rijkdommen in zee-, kust- en zoetwatergebieden. 